\title{
Article
}

\section{Higher Integrin Alpha 3 Beta1 Expression in Papillary Thyroid Cancer Is Associated with Worst Outcome}

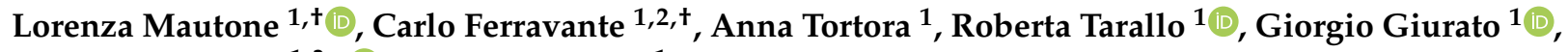 \\ Alessandro Weisz ${ }^{1,3, *(D)}$ and Mario Vitale ${ }^{1, *}$ \\ 1 Department of Medicine, Surgery and Dentistry, University of Salerno, 84081 Baronissi, Italy; \\ lorenza.mautone@gmail.com (L.M.); carlo.ferravante@unina.it (C.F.); anntortora@unisa.it (A.T.); \\ rtarallo@unisa.it (R.T.); ggiurato@unisa.it (G.G.) \\ 2 Genomix4Life, 84081 Baronissi, Italy \\ 3 Genome Research Center for Health-CRGS, University of Salerno Campus of Medicine, 84081 Baronissi, Italy \\ * Correspondence: aweisz@unisa.it (A.W.); mavitale@unisa.it (M.V.); Tel.: +39-089-965-043 (A.W.); \\ +39-089-672-753 (M.V.) \\ + Both authors contributed equally to this work.
}

Citation: Mautone, L.; Ferravante, C.; Tortora, A.; Tarallo, R.; Giurato, G.; Weisz, A.; Vitale, M. Higher Integrin Alpha 3 Beta1 Expression in Papillary Thyroid Cancer Is Associated with Worst Outcome. Cancers 2021, 13, 2937. https://doi.org/10.3390/ cancers13122937

Academic Editor: Vasyl Vasko

Received: 19 May 2021

Accepted: 7 June 2021

Published: 11 June 2021

Publisher's Note: MDPI stays neutral with regard to jurisdictional claims in published maps and institutional affiliations.

Copyright: (c) 2021 by the authors. Licensee MDPI, Basel, Switzerland. This article is an open access article distributed under the terms and conditions of the Creative Commons Attribution (CC BY) license (https:// creativecommons.org/licenses/by/ $4.0 /)$.
Simple Summary: Integrins are cell-extracellular matrix adhesion molecules considered functionally related to the development of cancer metastasis. Starting from a large dataset of mRNA-seq of papillary thyroid carcinoma (PTC), we investigated the potential role of integrins in the clinical course of PTC patients. Results showed that the PTC "classical" and "tall cell" histology variants display a more similar integrin expression profile with respect to the 'follicular' variant. Interestingly, the BRAFV600E mutation was found to be associated with a higher expression of integrins compared to RAS mutations. The integrin subunit ITGA3 was associated with advanced disease stage, lymph node metastasis, extrathyroidal extension, high-risk, and a worst prognosis. In vitro assays with PTC cell lines demonstrated the role of the $\alpha 3 \beta 1$ integrin in cell motility and invasion, evidence that supports the role of this adhesion molecule in tumor progression. These results demonstrate the existence of a PTC-specific integrin expression signature that correlates with histopathology, specific driver gene mutations, and aggressiveness of the disease.

Abstract: Integrins are cell-extracellular matrix adhesion molecules whose expression level undergoes quantitative changes upon neoplastic transformation and are considered functionally related to the development of cancer metastasis. We analyzed the largest mRNA-seq dataset available to determine the expression pattern of integrin family subunits in papillary thyroid carcinomas (PTC). ITGA2, 3, $6, \mathrm{~V}$, and ITGB1 integrin subunits were overexpressed in PTC compared to normal thyroid tissue. The PTC histology variants "classical" and "tall cell" displayed a similar integrin expression profile with a higher level of ITGA3, ITGAV, and ITGB1, which differed from that of the "follicular" variant. Interestingly, compared to RAS mutations, BRAFV600E mutation was associated with a significantly higher expression of integrins. Some integrin subunits were associated with advanced disease stage, lymph node metastasis, extrathyroidal extension, and high-risk groups. Among them, ITGA3 expression displayed the highest correlation with advanced disease and was associated with a negative prognosis. In vitro scratch assay and Matrigel invasion assay in two different PTC cell lines confirmed $\alpha 3 \beta 1$ role in cell motility and invasion, supporting its involvement during tumor progression. These results demonstrate the existence of a PTC-specific integrin expression signature correlated to histopathology, specific driver gene mutations, and aggressiveness of the disease.

Keywords: integrins; thyroid cancer; BRAF mutation

\section{Introduction}

Survival of many eukaryotic cell, including epithelial cells, requires appropriate interactions between adhesion molecules and the extracellular matrix (ECM). These interactions 
are deeply altered in cancer cells, enabling them to invade surrounding tissues, survive, and form secondary tumors [1].

Integrins are the predominant cell surface receptors of ECM proteins such as fibronectin (FN), laminin, vitronectin (VN), and collagen (CO) [2]. These transmembrane heterodimers are composed of a common $\beta 1$ chain noncovalently associated with a distinctive $\alpha$-subunit, whose level of expression undergoes quantitative changes upon differentiation, neoplastic transformation, and hormone or cytokine induction [3,4]. At least $18 \alpha$ and $8 \beta$ subunits are known in Humans, generating 24 heterodimers, many of which recognize FN, $\mathrm{VN}, \mathrm{CO}$, and several other large glycoproteins. Integrins bind to ECM cluster in subcellular structures known as focal adhesions. These sites provide a structural link between the actin cytoskeleton and the extracellular matrix and control signal transduction pathways that modulate proliferation, differentiation, survival, migration, and tumorigenesis in many cell types.

Thus far, integrin expression in normal and pathological thyroid cells has been analyzed mainly by immunodetection and RT-PCR, but their role in thyroid tumorigenesis has been poorly investigated. Alpha3 $\beta 1$ and $\alpha \mathrm{V} \beta 3$ are the most abundant integrins in normal thyroid cells, and to a lesser extent $\alpha 1 \beta 1, \alpha 2 \beta 1$, and $\alpha 6 \beta 1$ [5-9]. These receptors' expression is modulated by cell status (i.e., cell-to cell contact) and tumor transformation [10]. Increased expression of $\alpha 2, \alpha 5, \alpha 6$, and $\beta 4$ integrin subunits have been documented in different thyroid tumor histotypes, while $\alpha 4$ gave inconsistent results $[5,6,11-14]$. Besides structural functions bridging ECM to the cytoskeleton, integrin activation has additional crucial functions in normal and neoplastic thyroid cells. For example, $\alpha \mathrm{V} \beta 3$ binding to FN is necessary for survival and promotes the proliferation of normal thyrocytes [15-17]. Several studies in cell models and primary tumors demonstrated the biological role and potential clinical impact of integrins in thyroid tumors. Expression of integrin subunit $\beta 4$ correlates with lymph node metastasis in papillary carcinomas, and integrin subunit $\beta 6$ significantly correlates with recurrence of follicular thyroid carcinoma (FTC) [18,19]. Inhibition of $\alpha 5 \beta 1$ binding to ECM prevents attachment of FTC cell lines to the bone matrix [20], while RET-induced cell adhesion and migration of papillary thyroid carcinoma (PTC) cell lines required $\beta 1$ and $\beta 3$ integrins in vitro and in a mouse tumor xenograft model [21]. Finally, knock-down of $\beta 4$ subunit expression reduced the proliferation, migration, and anchorage-independent growth of anaplastic thyroid carcinoma cells in vitro and xenograft tumor growth in vivo [22].

The availability of gene expression large datasets generated by RNA sequencing provided us the opportunity to extensively investigate the expression of integrin subunits in thyroid cancer samples. Results demonstrate that integrin gene expression hallmarks PTC subtypes and that higher $\alpha 3 \beta 1$ expression is associated with a worst outcome of the disease.

\section{Materials and Methods}

\subsection{Samples Collection}

The analysis has been performed considering dataset TCGA-THCA, downloaded from The Cancer Genome Atlas (TCGA) (https: / / portal.gdc.cancer.gov / accessed date 21 April 2020). TCGA-THCA dataset comprised raw-counts data with the gene expression profile of 496 PTC tumor samples and 58 solid tissue samples: 358 classical Papillary Thyroid Carcinoma (PTCcl); 37 Tall Cell PTC (PTCtc); 101 Follicular Variant of PTC (PTCfv). Matching clinicopathological data were downloaded from cBioPortal for Cancer Genomics (http://www.cbioportal.org/ accessed date 21 April 2020) [23]. Raw-counts data with the gene expression profile of 243 PTC samples where lymphocytes and stromal cells contamination was assessed were downloaded from TCGA (https:/ / portal.gdc.cancer. gov/projects/TCGA-THCA accessed date 21 April 2020). 


\subsection{Data Analysis}

Data analysis of TCGA-THCA data has been performed as described by Salvati et al. [24]. In detail, HTseq counts data from TCGA-THCA project were imported in $\mathrm{R}$ package DESeq2 v1.26.0 (R version 3.6.3) [25]. Differential expression was reported as fold change $\geq|1.5|$ along with associated adjusted $p$ values (FDR $\leq 0.05$ ), computed according to Benjamini-Hochberg [26].

\subsection{Cell Lines, Antibodies, Immunofluorescence and Flow Cytometric Analysis}

TPC-1 and BCPAP (Leibniz Institute DSMZ, Braunschweig, Germany) were papillary thyroid cancer stable cell lines harboring the RET/PTC and BRAFV600E oncogenes, respectively. The cells were cultured at $37^{\circ} \mathrm{C}, 5 \% \mathrm{CO}_{2}$ in DMEN, $10 \%$ calf serum (CS).

Monoclonal antibody to $\alpha 3$ was purchased from Santa Cruz Biotechnology (Dallas, TE, USA); fluorescein-conjugated anti-mouse antibody was from Sigma-Aldrich (St. Louis, MI, USA). Cells were then analyzed by flow cytometry using a FACScan apparatus (Becton Dickinson Co., Mountain View, CA, USA). Flow cytometric analysis was performed as follows: cells were harvested by trypsin-PBS, incubated with the primary monoclonal antibody for $1 \mathrm{~h}$ at room temperature (RT) in $0.5 \%$ BSA-PBS, washed with the same buffer, and incubated again with the secondary fluorescein-conjugated antibody for $30 \mathrm{~min}$ at RT. Cells were resuspended in BSA-PBS and analyzed by flow cytometry.

\subsection{Downregulation of $\alpha 3$ Expression by siRNA}

The cells were transfected with 3 unique 27mer ITGA3 siRNA duplexes or scrambled negative control siRNA duplex $(10 \mathrm{nM})$ following the manufacturer protocol (OriGene, Rockville, MD, USA). Residual $\alpha 3$ expression was assessed $48 \mathrm{~h}$ after transfection by flow cytometry with anti- $\alpha 3$ antibody. In BCPAP and TPC- 1 cell lines, residual $\alpha 3$ expression was $30.04 \%+/-3.1$ and $29.5 \%+/-3.8$, respectively (mean of 4 independent experiments).

\subsection{Cell Attachment Assay}

The assay was performed in 96-well flat-bottomed microtiter plates. The wells were filled with $100 \mu \mathrm{L}$ of the appropriate dilution in PBS of FN, CO, or LM (Collaborative Research, Bedford, MA, USA). After overnight incubation at $4{ }^{\circ} \mathrm{C}$, the plates were washed with PBS, filled with $100 \mu \mathrm{L} 1 \%$ heat-denatured BSA, and incubated for $1 \mathrm{~h}$ at room temperature. Then, plates were washed and filled with $100 \mu \mathrm{L} /$ well PBS, $0.9 \mathrm{mmol} / \mathrm{L} \mathrm{CaCl}$ 2, and $0.5 \mathrm{mmol} / \mathrm{L} \mathrm{MgCl} 2$ containing $70 \times 10^{4}$ cells. After $1 \mathrm{~h}$ at $37^{\circ} \mathrm{C}$, plates were gently washed 3 times with PBS, and the attached cells were fixed with $3 \%$ paraformaldehyde for $10 \mathrm{~min}$, followed by $2 \%$ methanol for $10 \mathrm{~min}$, and finally stained with $0.5 \%$ crystal violet in $20 \%$ methanol. After $10 \mathrm{~min}$, the plates were washed with tap water, the stain was eluted with a solution of $0.1 \mathrm{~mol} / \mathrm{L}$ sodium citrate, $\mathrm{pH} 4.2$, in $50 \%$ ethanol, and the absorbance at $540 \mathrm{~nm}$ was measured by a spectrophotometer. In the adhesion inhibition assay, the cells were co-incubated with $1 \mu \mathrm{g} / \mathrm{mL}$ anti- $\alpha 3$ monoclonal antibody in plates previously coated with $5 \mu \mathrm{g} / \mathrm{mL}$ FN, CO, or LM. Alternatively, the adhesion assay was performed with cells transfected with ITGA3 siRNA or scrambled negative control siRNA. All experiments were performed in quadruplicate.

\subsection{In Vitro Scratch Assay}

Cell plates were coated with ECM with a mix of PBS $100 \mu \mathrm{g} / \mathrm{mL}$ LM, FN, and CO incubated for $24 \mathrm{~h}$ at $4{ }^{\circ} \mathrm{C}$. TPC-1 or BCPAP cells were seeded to obtain a confluent monolayer. After $24 \mathrm{~h}$, a scratch was created with a p200 pipet tip, and the anti- $\alpha 3$ integrin subunit monoclonal antibody was added to a fresh medium at a $1 \mu \mathrm{g} / \mathrm{mL}$ concentration. Alternatively, the cells were transfected with ITGA3 siRNA or scrambled negative control siRNA, plated on ECM coated plates and, after $24 \mathrm{~h}$, the scratch was created. The cells were photographed, and scratches were measured by ImageJ software (https://imagej.nih. gov accessed date 10 November 2020) after $24 \mathrm{~h}$. After $48 \mathrm{~h}$ of transfection, residual $\alpha 3$ expression was assessed by flow cytometry with anti- $\alpha 3$ antibody. 


\subsection{Invasion Assay}

$2 \times 10^{5}$ cells were plated in the upper chamber on a 24-well transwell polycarbonate membrane with $8.0 \mu \mathrm{m}$ pore size (Corning, New York, NY, USA), previously coated with $50 \mu \mathrm{L}$ of $3 \mathrm{mg} / \mathrm{mL}$ Matrigel (Corning) and kept at $37^{\circ} \mathrm{C}$ for $24 \mathrm{~h}$ to ensure solidification. Cells were placed in $150 \mu \mathrm{L}$ of serum-free DMEM, $0.1 \%$ BSA, whereas the bottom chamber media contained $10 \% \mathrm{CS}$. After $48 \mathrm{~h}$, the cells on the top of the membrane were carefully removed by a cotton-tipped applicator. The cells on the bottom of the membrane were fixed with 3\% paraformaldehyde for $10 \mathrm{~min}$, followed by $2 \%$ methanol for $10 \mathrm{~min}$, and finally stained with $0.5 \%$ crystal violet in $20 \%$ methanol. After $10 \mathrm{~min}$, the membranes were washed with tap water, the stain was eluted with a solution of $0.1 \mathrm{~mol} / \mathrm{L}$ sodium citrate, $\mathrm{pH}$ 4.2 , in $50 \%$ ethanol, and the absorbance at $540 \mathrm{~nm}$ was measured by a spectrophotometer.

\subsection{Statistical Analysis}

All data were presented as mean \pm standard deviation. We compared groups using the Wilcoxon test, and statistical significance was defined as a $p$-value less than 0.05 . Comparisons of integrin expression and clinical features were conducted by one-way analysis of variance (ANOVA), and statistical significance was assumed for $p<0.01$. Univariate regression analysis was performed using the Spearman rank correlation test.

\section{Results}

\subsection{Effect of Non-Tumoral Cells on Integrin Expression Assessment}

Some PTC samples of the TCGA dataset were contaminated by lymphocytes and stromal cells. Both these cells have their own integrin repertoire that can interfere with the correct assessment of integrin expression in tumoral cells. To determine the effect of lymphocytic infiltration, we compared the counts of PTC samples with $<15 \%$ of lymphocytes $(n=130)$ vs. those with $15-40 \%(n=8)$ (Table S1). Only the integrin subunits known to be expressed by leukocytes (ITGA 4, D, L, M, X, ITGB2) were significantly higher in samples contaminated by lymphoreticular cells. Similarly, to determine the effect of stromal cells, we compared the counts of PTC samples with $<95 \%$ of stromal cells $(n=60)$ vs. those with $>30 \%(n=53)$ (Table S2). Only the integrin subunits ITGA1 and ITGA5 were significantly higher in samples contaminated by stromal cells. This analysis indicated that the counts of ITGA 2, 3, 6, V, and ITGB1 referred to the mRNA expression of PTC tumor cells and were not affected by the presence of lymphocytic or stromal contamination.

\subsection{Expression of Integrin Subunits mRNA in Normal Thyroid Tissue}

Analysis of the TCGA-TCA database confirmed the results previously obtained by immunodetection in normal thyroid tissue. ITGA3, ITGAV, and ITGB1 were the most abundant integrin subunits, followed by ITGA1 and ITGB3 (Figure 1). Very low counts of ITGA5 and ITGA6 mRNA were present. The combination of these $\alpha$ and $\beta$ subunits corresponded to some well-documented heterodimers, detected by immunodetection $(\alpha 3 \beta 1, \alpha \mathrm{V} \beta 3, \alpha 1 b 1$ and $\alpha 5 \beta 1)$. Notably, the expression of main subunits mRNA was quite constant among samples, as documented by their low standard deviation ( $\alpha 3=52 \%$; $\alpha \mathrm{V}=37 \%, \beta 1=28 \% ; \beta 3=53 \%$ ). PTC displayed an increased expression of ITGA2, 3, 6, V, and ITGB1 $(p<0.001)$.

\subsection{Comparative Analysis of Integrin Subunits in PTC Variants}

TCGA included a large repository of RNA-seq data relative to PTC, comprising classical (PTCcl), follicular (PTCfv), and Tall Cell variants (PTCtc). The analysis of integrin mRNA expression of this dataset allowed a comparative analysis between PTC variants (Figure 2). PTCtc displayed higher expression of ITGA2, ITGA3, ITGAV, and ITGB1 subunits. PTCfv displayed a significantly lower mRNA expression of ITGA2, 3, V, and ITGB1 compared to PTCcl and PTCtc. Between PTCcl and PTCtc, only ITGA3 and ITGAV had a $p<0.001$. Thus, the integrin expression profile highlighted a similarity among PTCcl and PTCtc that distinguishes them from PTCfv. 


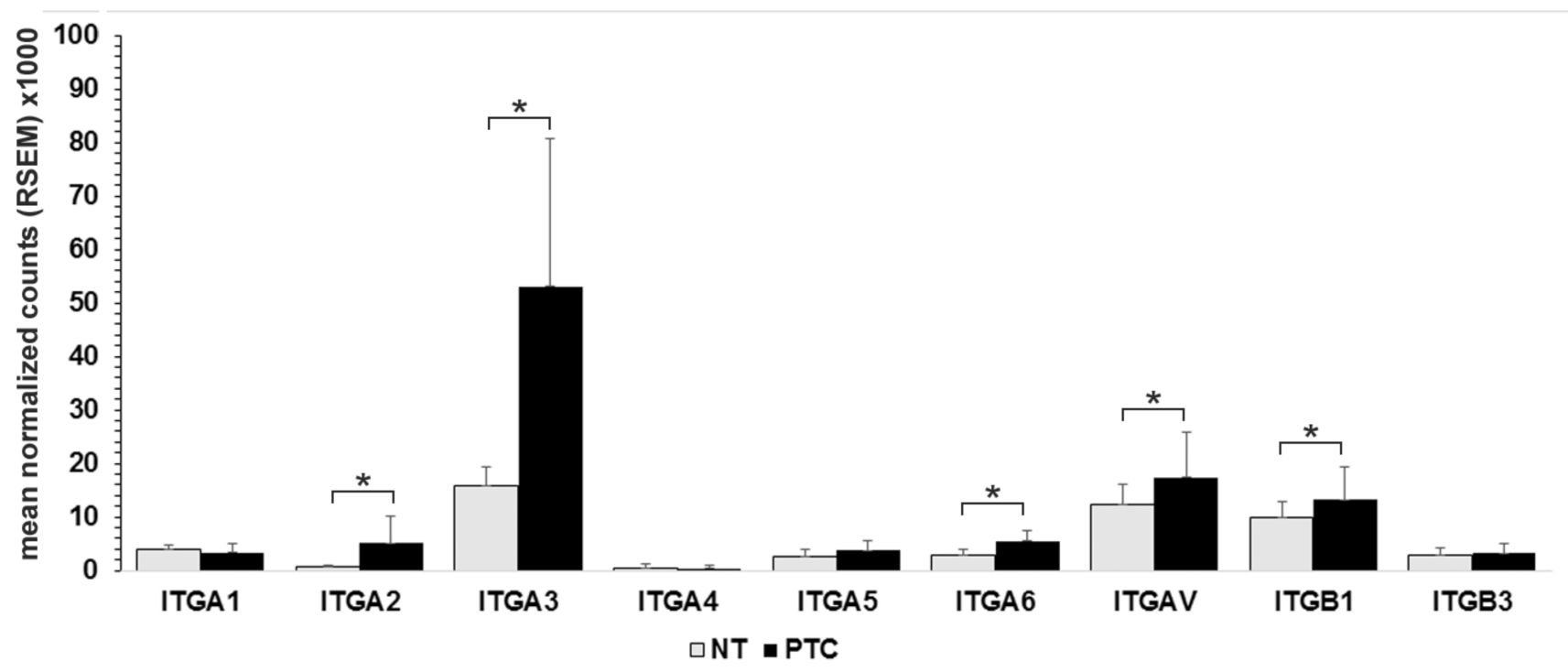

Figure 1. Integrin subunits expression in TCGA database. Mean and standard deviation of mRNA integrin subunits of papillary thyroid carcinoma PTC (black bars, $n=321$ ) and normal thyroid tissue (NT, gray bars, $n=58$ ). Wilcoxon $p<0.001$.

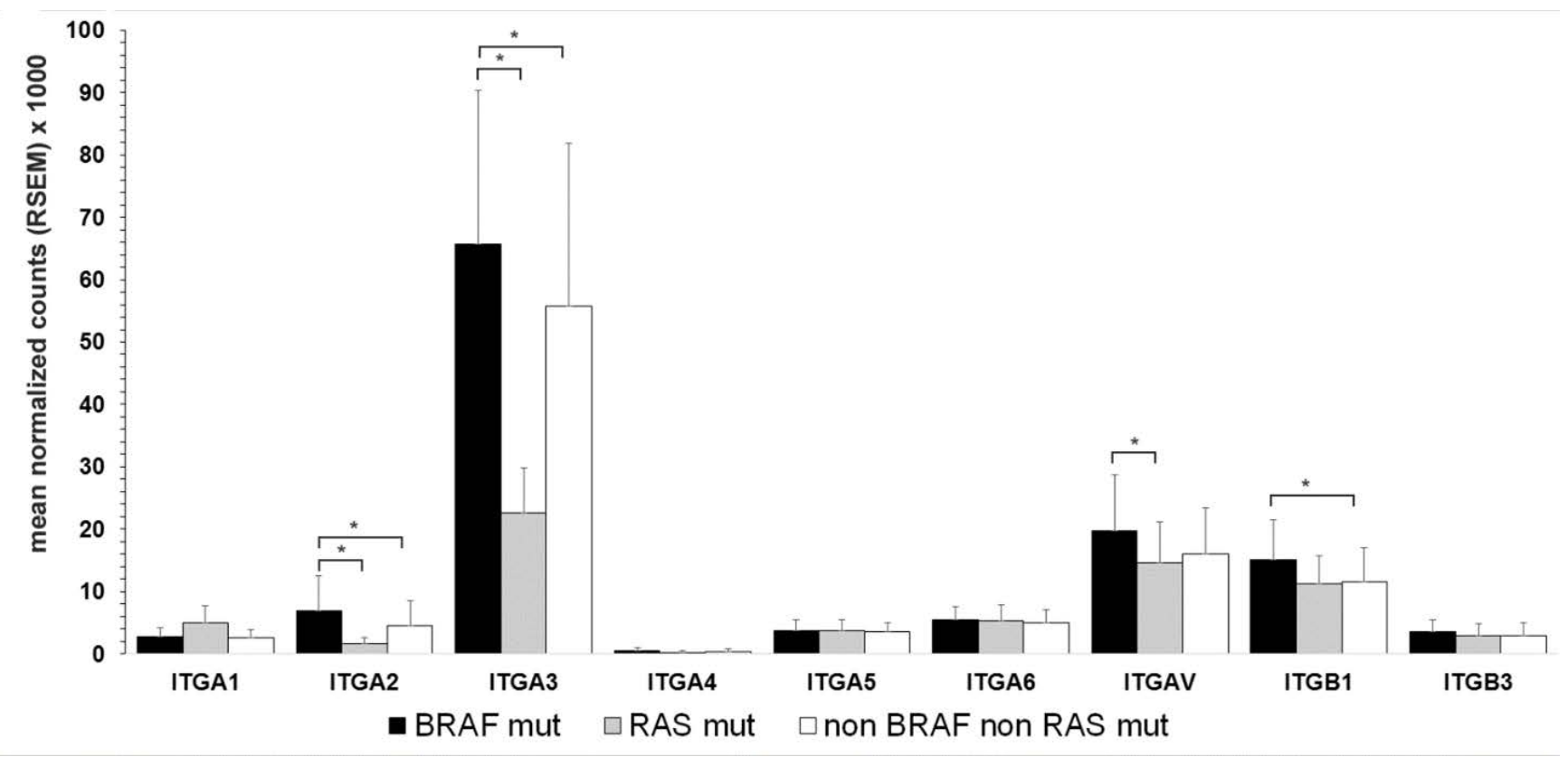

Figure 2. Integrin subunits expression in PTC variants. Mean and standard deviation of mRNA integrin subunits of PTC classical (PTCcl, $n=358$ ), follicular (PTCfv, $n=101$ ), and tall cell variants (PTCtc, $n=37)$. Wilcoxon: * $p<0.001$.

\subsection{Association of Integrin Expression and Driver Gene Mutations}

Of the 321 PTCcl analyzed, the BRAFV600E mutation was detected in 205 and mutated RAS in 43. In general, the expression profile of integrin subunits in BRAF mutant, RAS mutant, and non-BRAF non-RAS mutant PTC was similar, with higher expression levels in BRAF mutant tumors (Figure 3). Variance analysis of the three tumor groups demonstrated a significant difference in all subunits except for ITGA 1, 5, and 6 . The largest difference occurred between BRAF mutants and RAS mutant PTCcl. The higher ratios BRAF mutants/RAS mutants among $\alpha$ subunits were observed for ITGA2 and ITGA3, with a fold-change of 4.2 and $3.3(p<0.0001)$, respectively. Cumulative analysis of all three variants of PTC produced identical results. 


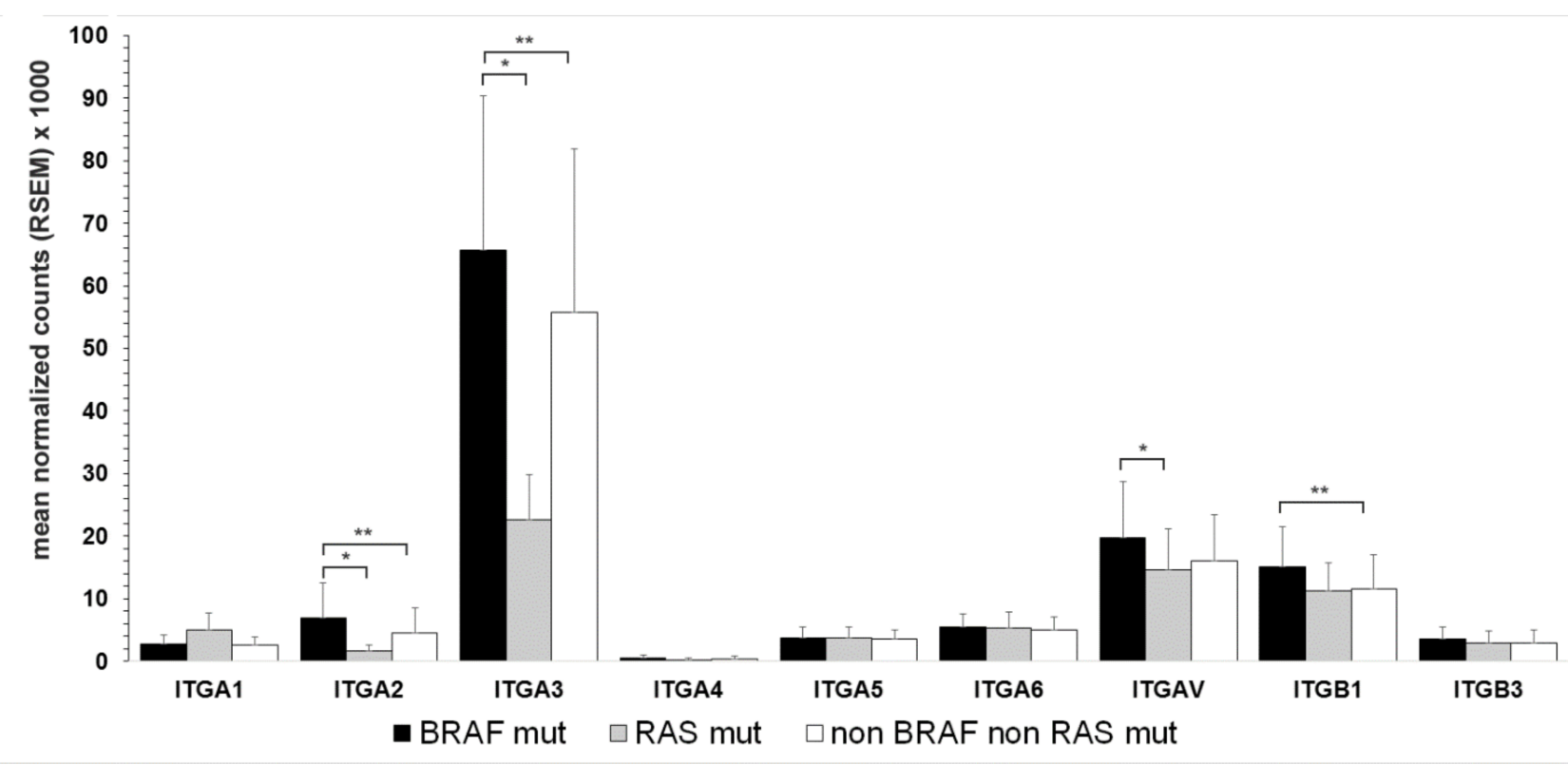

Figure 3. Correlation between integrin expression and driver mutations in PTCcl. Integrin subunits expression were determined in PTCCl with BRAF mutation (BRAF mut), RAS mutation (RAS mut) or none of both (non BRAF non-RAS). Mean and standard deviation; ANOVA $p<0.01$ for all subunits except for ITGA 4, 5, and 6. Wilcoxon: ${ }^{*} p<0.0001$, ** $p<0.001$.

\subsection{Association of Integrin Subunits Expression and Clinical Features}

We analyzed the correlation between integrin subunits expression and the Thyroid Differentiation Score (TDS), a single metric parameter designed by the expression level of 16 thyroid metabolism and function genes [27]. ITGA1 positively correlated with the TDS, while ITGA2, ITGA3, and ITGA4 negatively correlated with the TDS, with ITGA3 being the most significant $(R=-0.71, p<0.0001)$ (Figure $4 A$, Table 1$)$. Advanced stages were associated with integrin subunits: stage IV with ITGA 3 and stage III with ITGA 2 (Figure 4B, Table 2). The expression patterns of most integrin subunits were associated with lymph node metastasis (Table 3), extrathyroidal extension (Table 4), and high risk of recurrence (Table 5). In addition, in this case, the correlation was higher for ITGA3 (Figure 4C,D). High risk of tumor recurrence, according to the 2015 American Thyroid Association guidelines [28], was associated with higher ITGA3 expression, whereas higher expression of ITGA2 and ITGAV correlated with intermediate-risk (Figure 4E, Table 5). Disease-free survival analysis showed that tumors with higher expression of ITGA2 or ITGA3 had a shorter time between tumor recurrences. Tumors with ITGA2 above the median had a hazard ratio for disease recurrence of 1.9, $p=0.039$. Tumors with ITGA3 expression above the median had higher risk of recurrence log-rank $p=0.013$, hazard ratio $=2.1, p=0.015$ (Figure $4 \mathrm{~F})$.

Table 1. Spearman analysis of the correlation between integrin subunits and Differentiation score as described in [27].

\begin{tabular}{ccc}
\hline Subunit & $\mathbf{R}$ & $p$ \\
\hline ITGA1 & 0.51 & $<0.0001$ \\
ITGA2 & -0.50 & $<0.0001$ \\
ITGA3 & -0.71 & $<0.0001$ \\
ITGA4 & -0.17 & 0.0043 \\
ITGAV & -0.25 & 0.0024 \\
ITGB1 & -0.24 & 0.0034 \\
\hline
\end{tabular}




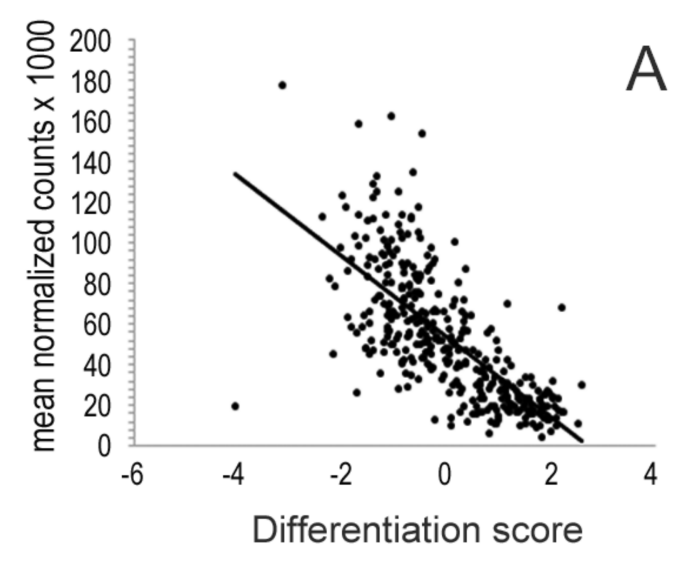

C

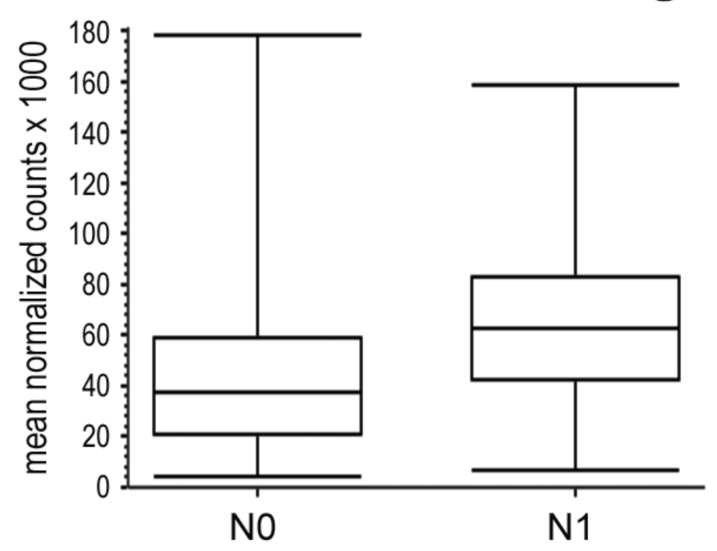

Lymph node metastasis

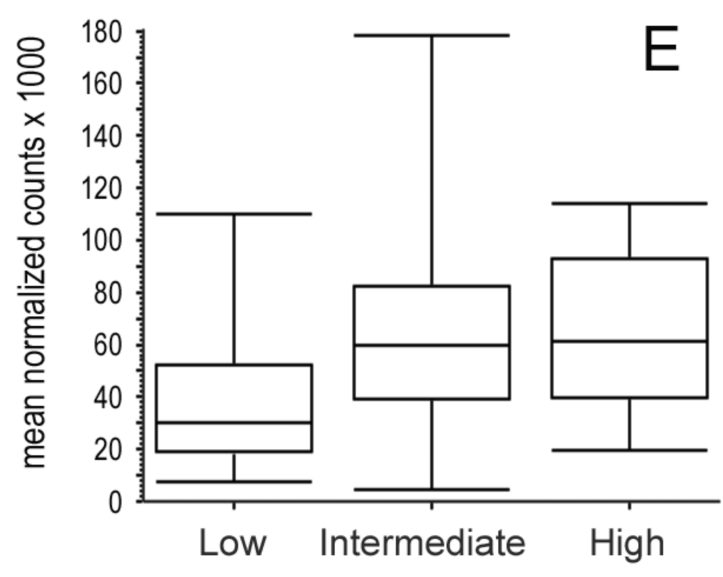

Estimated risk of tumor recurrence

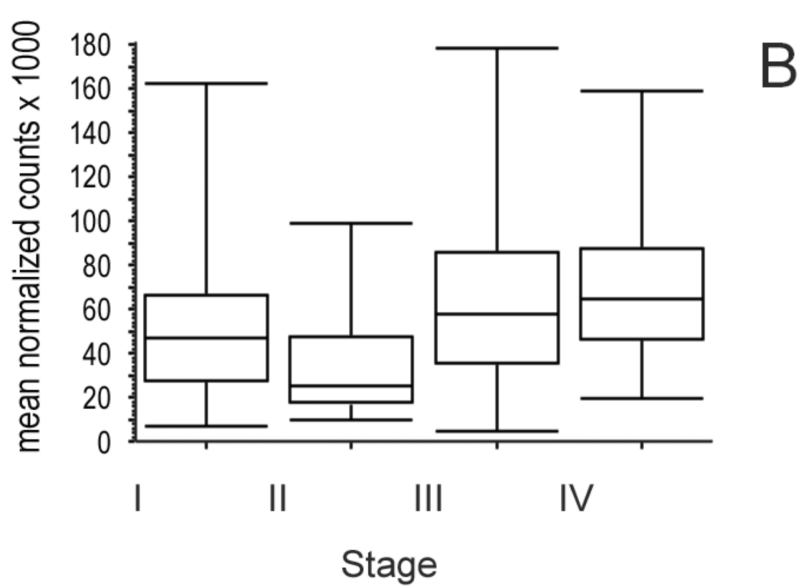

D

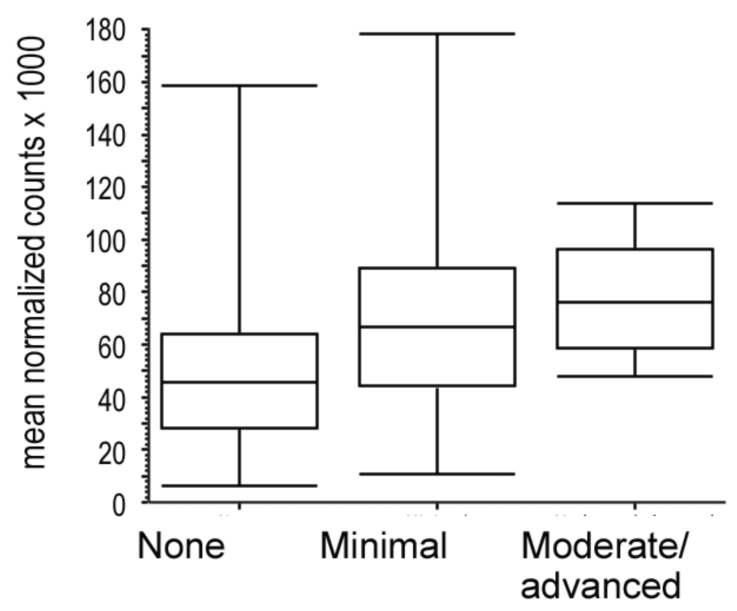

Extrathyroidal extension

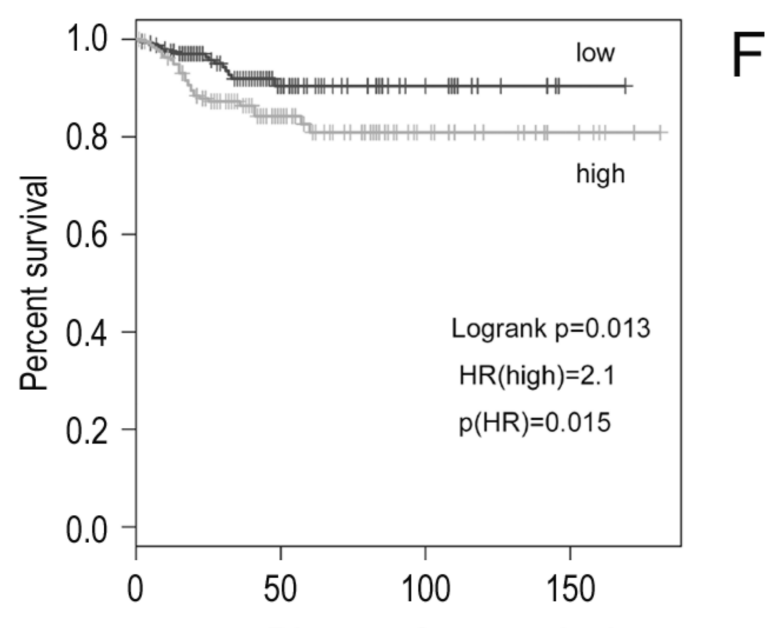

Disease-free survival

Figure 4. Correlation between ITGA3 and differentiation score (A), disease stage (B), lymph node metastasis (C), extrathyroidal extension (D), and estimated risk of tumor recurrence (E). For all analysis $p<0.0001$. (F) Kaplan-Meier disease-free survival plot for ITGA3. Low and high refer to the median mRNA expression. Log-rank $p=0.013$, hazard ratio $=2.1$, $p=0.015$. 
Table 2. Mean gene expression and ANOVA analysis of the correlation with disease stage. Only significant data are reported. Stage IV included both IVA and IVC.

\begin{tabular}{cccccc}
\hline \multicolumn{7}{c}{ STAGE } \\
\hline Subunit & I & II & III & IV & $p$ \\
\hline ITGA1 & 3437 & 4551 & 2917 & 2688 & $<0.0001$ \\
ITGA2 & 5179 & 3198 & 5695 & 5133 & 0.0417 \\
ITGA3 & 50620 & 35950 & 60690 & 68806 & $<0.0001$ \\
\hline
\end{tabular}

Table 3. Mean gene expression and Wilcoxon analysis for lymph node metastasis. Only significant data are reported.

\begin{tabular}{cccc}
\hline Subunit & N0 & N1 & $p$ \\
\hline ITGA1 & 3637 & 2894 & 0.0001 \\
ITGA2 & 4051 & 6251 & $<0.0000$ \\
ITGA3 & 44,777 & 64,078 & $<0.0000$ \\
ITGAV & 15,126 & 19,600 & $<0.0000$ \\
ITGB1 & 11,763 & 14,709 & $<0.0000$ \\
\hline
\end{tabular}

Table 4. Mean gene expression and ANOVA analysis of the correlation with extrathyroidal extension. Only significant data are reported.

\begin{tabular}{ccccc}
\hline & \multicolumn{3}{c}{ Estrathyroidal Extension } \\
\cline { 2 - 5 } Subunit & None & Minimal & $\begin{array}{l}\text { Moderate/ } \\
\text { Advanced }\end{array}$ & $p$ \\
\hline ITGA1 & 3632 & 2770 & 2426 & $<0.0001$ \\
ITGA2 & 4284 & 7124 & 5963 & $<0.0001$ \\
ITGA3 & 46,027 & 69,104 & 77,692 & $<0.0001$ \\
ITGAV & 16,035 & 20,639 & 20,250 & $<0.0001$ \\
ITGB1 & 12,503 & 14,808 & 17,491 & $<0.0001$ \\
\hline
\end{tabular}

Table 5. Estimated risk of tumor recurrence based on the 2009 American Thyroid Association guidelines.

\begin{tabular}{ccccc}
\hline & \multicolumn{4}{c}{ Risk } \\
\cline { 2 - 5 } Subunit & Low & Intermediete & High & $p$ \\
\hline ITGA1 & 4087 & 2929 & 2651 & $<0.0001$ \\
ITGA2 & 3321 & 6218 & 5497 & $<0.0001$ \\
ITGA3 & 37,455 & 62,487 & 65,943 & $<0.0001$ \\
ITGA4 & 342 & 446 & 269 & 0.02108 \\
ITGAV & 14,544 & 19,230 & 17,161 & $<0.0001$ \\
ITGB1 & 11,686 & 14,119 & 14,403 & 0.0003 \\
\hline
\end{tabular}

\subsection{Adhesion of Cancer Cell Lines to ECM}

Two well-characterized papillary thyroid cancer cell lines, TPC-1 and BCPAP, harboring the RET/PTC and BRAFV600E oncogenes, respectively, were used to investigate the role of the integrin $\alpha 3 \beta 1$ in adhesion to ECM [29]. Cell attachment assays were performed in microtiter plates coated with different concentrations of FN, CO, or LM (Figure 5A). Both cell lines displayed a weak adhesion to LM compared to FN and CO. Integrin $\alpha 3 \beta 1$ mediated the adhesion to LM as demonstrated by the inhibitory effect of the anti- $\alpha 3$ antibody, while it was ineffective on adhesion to FN and CO (Figure 5C). The cells transfection with ITGA3 siRNA oligo duplexes $48 \mathrm{~h}$ before the adhesion assay reduced $\alpha 3$ expression to 30\% (Figure 5B) and inhibited LM adhesion to 59\% (Figure 5C). 

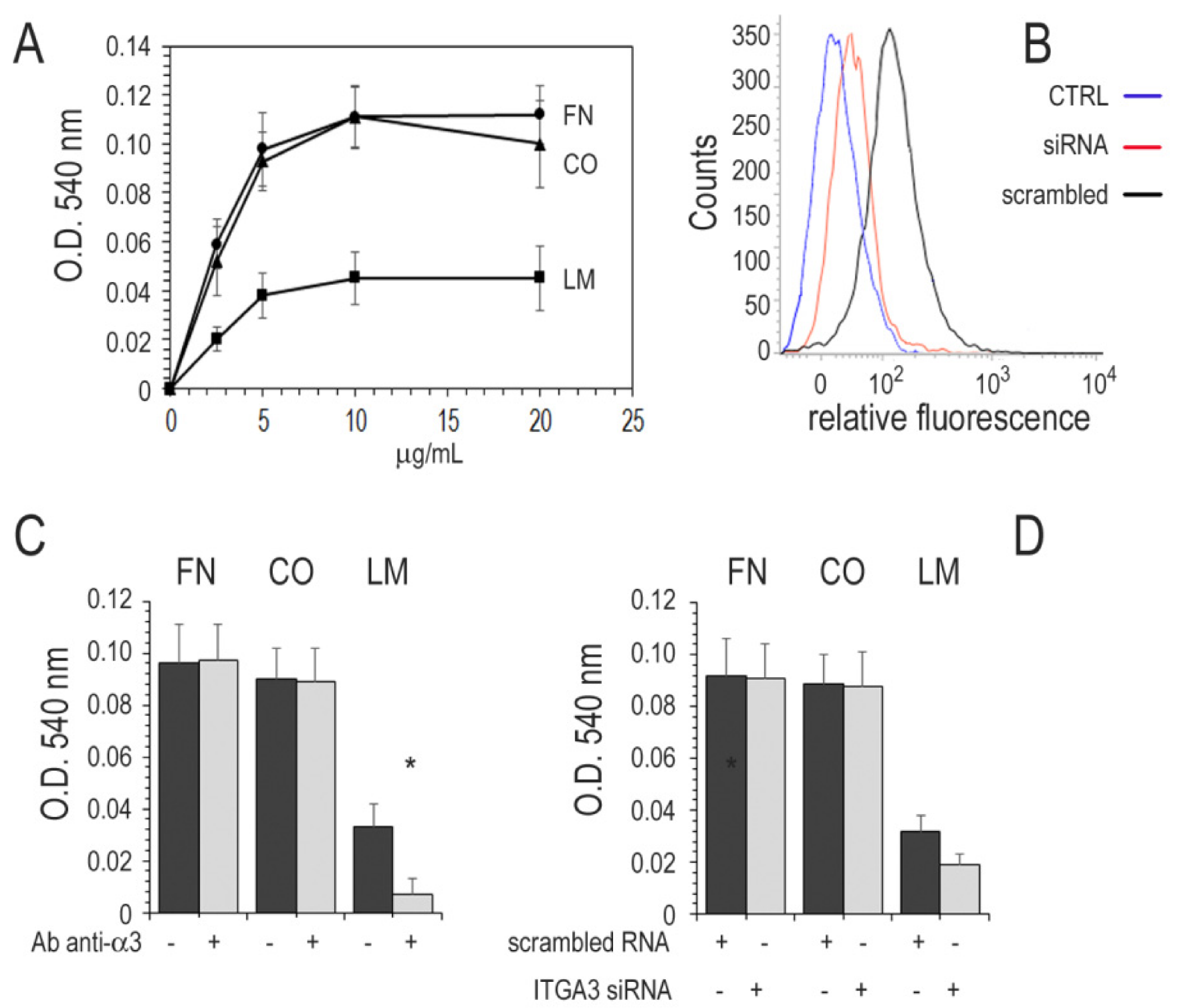

Figure 5. Cell attachment to ECM and role of $\alpha 3 \beta 1$. (A) Microtiter wells were coated with different concentrations of FN, CO, or LM and saturated with heat-denatured BSA. Cells in calcium-and magnesium-containing PBS were added and incubated at $37^{\circ} \mathrm{C}$ for $1 \mathrm{~h}$. The attached cells were measured as described in Materials and Methods. (B) The cells were transfected with ITGA3 siRNA duplexes (siRNA) or with scrambled RNA, and $\alpha 3$ expression was assessed after $48 \mathrm{~h}$ by flow cytometry with anti- $\alpha 3$ primary antibody (CTRL, no primary antibody). The mean inhibition of $\alpha 3$ expression of 4 experiments was about $70 \%$. (C) Microtiter wells were coated with $5 \mu \mathrm{g} / \mathrm{mL}$ ECM and saturated with BSA. Cells were added to the plates with $1 \mu \mathrm{g} / \mathrm{mL}$ of monoclonal antibody anti $\alpha 3$ subunit (Ab anti- $\alpha 3$ ). (D) Alternatively, an attachment assay was performed with cells transfected with ITGA3 siRNA or scrambled RNA. After $1 \mathrm{~h}$ at $37^{\circ} \mathrm{C}$, the plates were gently washed, and attached cells were measured as described. All experiments were performed in quadruplicate. ${ }^{*}, p<0.001$. Only experiments with BCPAP are shown, results in TPC-1 were all the same.

\subsection{Integrin $\alpha 3 \beta 1$ and Motility in Thyroid Cancer Cell Lines}

In vitro scratch assay was used to investigate the role of the integrin $\alpha 3 \beta 1$ in cell motility. The cells were plated in ECM coated wells and, after $24 \mathrm{~h}$, a scratch was created and measured immediately (Figure 6). The scratch was no more visible in untreated cells or after transfection with scrambled RNA (CTRL). The presence of an anti- $\alpha 3$ antibody added to the medium immediately after the scratch inhibited cells motility to $49 \%$ in BCPAP and $65 \%$ in TPC-1. The cells transfection with ITGA3 siRNA oligo duplexes $24 \mathrm{~h}$ before plating 
(48 $\mathrm{h}$ before the scratch was produced) reduced $\alpha 3$ expression to $30 \%$ and inhibited cells motility to $19 \%$ in BCPAP and $28 \%$ in TPC- 1 .
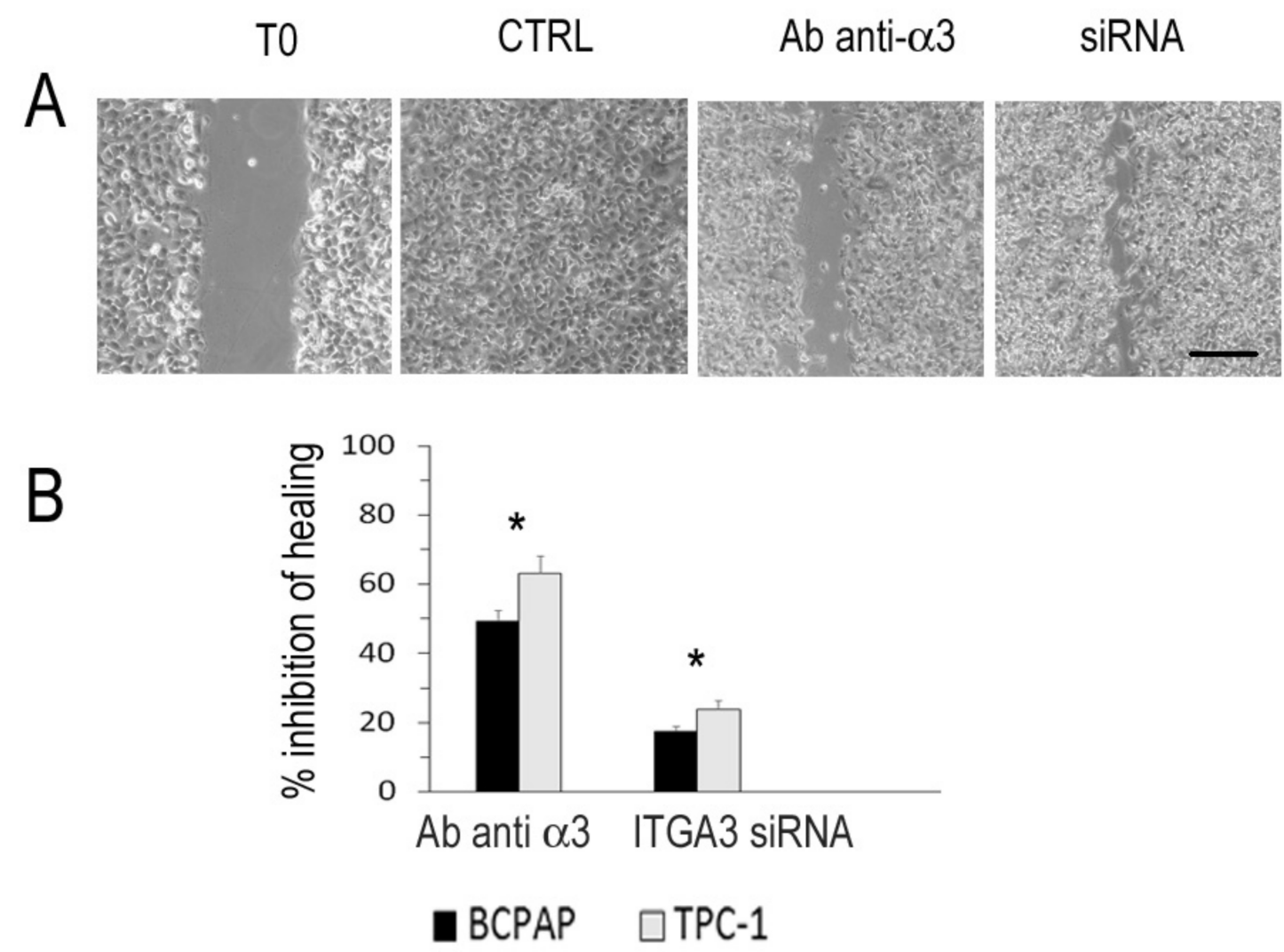

Figure 6. Scratch assay. BCPAP (A) and TPC-1 cells were plated in ECM coated wells, a scratch was produced (T0), and the healing process was photographed after $24 \mathrm{~h}$. The cells were untreated or transfected with scrambled oligos (CTRL), transfected with ITGA3 siRNA duplexes, or incubated with monoclonal antibody anti- $\alpha 3$ subunit (Ab anti- $\alpha 3$ ). Scale bar, $200 \mu \mathrm{m}$. Magnification $\times 200$. (B) Hedges distances were measured and reported as percentage of inhibition of healing. Standard deviations of triplicate experiments were $<5 \%$. ${ }^{*}, p<0.001$.

\subsection{Invasion Assay}

BCPAP and TPC- 1 were plated on top of a polycarbonate membrane coated with Matrigel, and cells migrating to the lower face of the membrane were assessed after $48 \mathrm{~h}$. The cells were incubated with or without $\mathrm{Ab}$ anti $\alpha 3$ at a final concentration of $1 \mu \mathrm{g} / \mathrm{mL}$ (upper and lower chamber). In separate experiments, the cells were transfected with ITGA3 siRNA or scrambled RNA (Figure 7). In both cell lines, Matrigel invasion was inhibited by the anti $\alpha 3$ antibody and by ITA3 siRNA. 


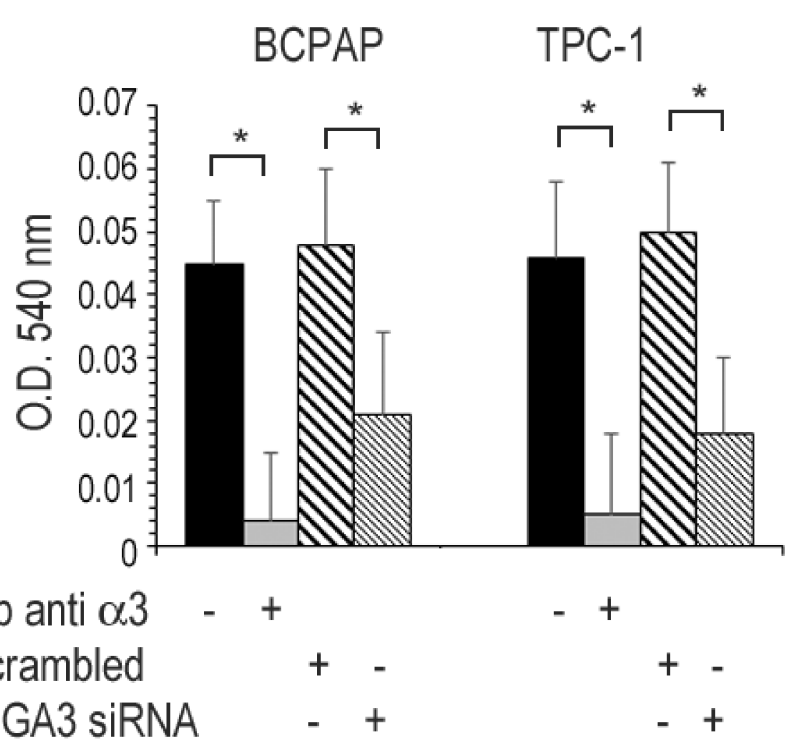

Figure 7. Matrigel invasion assay. Cells were plated on a polycarbonate membrane coated with Matrigel, then cultured for $48 \mathrm{~h}$. The cells on the top of the membrane were carefully removed, and attached cells on the bottom of the membrane stained by crystal violet and measured as described in the Materials and Methods. The cells were incubated with or without $\mathrm{Ab}$ anti $\alpha 3$ integrin subunit or, in separate experiments, the cells were transfected with ITGA3 siRNA or scrambled RNA. All experiments were performed in quadruplicate. ${ }^{*}, p<0.0001$.

\section{Discussion}

Reported results of gene expression analysis here confirmed previous immunodetection studies in normal thyroid cells. Considering $\alpha$ and $\beta$ subunits assembly in the natural heterodimers, only $\alpha 3 \beta 1, \alpha \mathrm{V} \beta 3$, and at a minor extent $\alpha 1 \beta 1$ and $\alpha 6 \beta 1$ receptors are expressed in normal thyroid cells. Thus, integrin repertoire in normal thyroid cells appears restricted but sufficient to enable the cell to bind $\mathrm{FN}, \mathrm{CO}$, and LM, besides other non-ECM proteins. These integrins have functional and structural properties, participating in thyroid cell survival and follicle structure. The $\alpha \mathrm{V} \beta 3$ receptor for FN and VN is a functional component of the cell-ECM interaction and plays a central role in FN-mediated survival in thyroid cells through complex signaling, involving p21 RAS, calcium/CaMKII, and PI3K/AKT $[8,16,17]$. The $\alpha 3 \beta 1$ integrin interacts with ECM proteins, including members of the LM family [30]. Among the five distinct LM isoforms, $\alpha 3 \beta 1$ preferentially binds to LM-10/11, a major basement membrane component of the thyroid follicle [31]. The distribution on the cell membrane of these two integrins is different in the normal thyroid cell. Alpha $V \beta 3$ is clustered in the focal adhesions while $\alpha 3 \beta 1$ is spread on the entire basal membrane in a polarized fashion, being located exclusively on the basal plasma membrane and at intercellular contact sites $[7,8]$.

Tumor transformation deeply alters the equilibrium between adhesion molecules and basal membrane. Invasive carcinomas generally show aberrant basement architecture and loss of LM around the epithelial structures [32]. Early thyroid immunohistochemical studies highlighted that adenomas and non-invasive FTC tend to preserve the basement membrane around the follicles while its partial or complete loss can be recognized in widely invasive FTC [33]. In contrast, PTC preserves basement membrane structure with abundant LM around the follicles [31]. More extended is the change of integrin expression in thyroid tumors. The polarized distribution of $\alpha 3 \beta 1$ and $\alpha \mathrm{V} \beta 3$ integrins on the cell membrane, a feature of normal thyroid cells, is lost while other integrin subunits are expressed de novo both in benign and malignant tumors [34]. The loss of polarized integrins expression on the cell surface inadenomas and carcinomas highlights a common biological alteration concerning cell-stroma interaction. 
Analysis of the TCGA database highlighted a defined difference between PTC subtypes with higher integrins expression in PTCcl and PTCtc, differing from PTCfv lower integrin expression. Thus, with respect to the integrin profile, PTCcl is closer to PTCtc than to PTCfv. However, when the TCGA database was generated, the histology subtype non-invasive follicular thyroid neoplasm with papillary-like nuclear features (NIFTP) had not yet been described. Therefore, a number of NIFTPs are present in the PTCfv and this may be responsible for the different integrin profiles of this variant compared to the others.

BRAF mutation was associated with higher expression of all integrin subunits and particularly to ITGA2, ITGA3, and ITGAV, contributing to the difference between integrin expression profiles of the three PTC histotypes, as BRAF mutation was the driver mutation in $64 \%$ and $82 \%$ of PTCcl and PTCtc and only $17 \%$ in PTCfv.

The $\alpha 2 \beta 1$ complex is the one with higher upregulation in thyroid carcinomas (up to 9-fold for ITGA2 vs. 2.5-fold for ITGA3 and ITGAV), although it is not the most abundant integrin expressed. This receptor, whose expression in benign and malignant thyroid tumors was previously detected by immunodetection, binds LM, COL, and heparan sulfate proteoglycan core protein, an integral component of the basement membrane [6,33]. Alpha $2 \beta 1$ is over-expressed in a variety of cancer cells and experimental evidence suggest that its aberrant expression might contribute to invasion, metastasis, and drug resistance in non-small cell lung, ovarian, and breast cancer, pancreatic ductal adenocarcinoma, and hepatocellular carcinoma, being associated with poor survival in pancreatic ductal adenocarcinoma and potential therapeutic target for gastric cancer [35-39]. Moreover, $\alpha 2 \beta 1$ has been investigated as a potential therapeutic target in thyroid tumors. In TPC-1, a PTC cell line, ropivacaine suppresses proliferation, invasion, migration, and accelerate apoptosis via regulation of ITGA2 expression [40]. In our analysis in PTC, ITGA2 is positively associated with stage III, lymph node metastasis, minimal extrathyroidal extension, and intermediate-risk tumors.

ITGA3 is the most expressed integrin subunit and the most strongly associated with aggressive disease, being found upregulated in stage IV, lymph node metastasis, moderate/advanced extrathyroidal extension, high-risk tumors, and shorter disease-free survival. Recently the role of ITGA3 in thyroid carcinogenesis has been investigated. Knockdown experiments in TPC-1 demonstrated that ZNF367, a member of the zinc finger protein family, regulates cellular adhesion, invasion, and migration through, at least in part, modulation of ITGA3 expression [41]. In TPC-1 cells, miR-524-5p inhibits cell viability, migration, invasion, apoptosis, and autophagy through targeting ITGA3 [42]. These and many correlation studies point to integrin $\alpha 3 \beta 1$ playing a role in thyroid carcinogenesis.

Invasion and metastasis are complex processes that require sequential events: adhesion, proteolysis of ECM, and migration. In principle, well-differentiated epithelial tumors commonly use collective migration mechanisms [43]. Collective migration requires a subset of highly mobile cells at the front that generate migratory traction. Cells at the leading margin engage integrins in anterior protrusions towards the ECM, whose components are degraded by surface proteases. For example, the serine integral membrane peptidase seprase, MMP1 (a collagenase), and MMP2 (a gelatinase) bind, respectively, $\alpha 3 \beta 1, \alpha 2 \beta 1$, and $\alpha \mathrm{v} \beta 3$ integrins [44,45]. A positive correlation between integrin function and invasion was shown for many tumors, including melanoma, ovarian, colorectal, and prostate cancer. The data reported here demonstrate that differentiated thyroid carcinomas similarly display a selective increase in integrin expression and a positive correlation with the disease aggressiveness.

\section{Conclusions}

Integrin expression profile is altered in PTC and correlates with histopathology subtype and specific driver gene mutations.

Integrin $\alpha 3 \beta 1$ is involved in PTC cell motility and invasion and is associated with advanced-stage disease, lymph node metastasis, extrathyroidal extension, high-risk, and a poor prognosis. 
Supplementary Materials: The following are available online at https: / www.mdpi.com/article/ 10.3390/cancers13122937/s1, Table S1: Effect of lymphocytic infiltration on integrin expression assessment. Table S2: Effect of stromal cells infiltration on integrin expression assessment.

Author Contributions: Conceptualization: R.T., A.W. and M.V.; informatics analysis: G.G.; writing and original draft preparation: L.M., C.F., A.T. and M.V.; writing, review and editing: all authors; funding acquisition: R.T., A.W. and M.V. All authors have read and agreed to the published version of the manuscript.

Funding: Work supported by: Italian Association for Cancer Research (grant number IG-23068), Regione Campania ('La Campania lotta contro il cancro' project Rare-Plat-Net, CUP: B63D18000380007) and Ministero dell'Istruzione, Università e Ricerca, programma PON R\&I 2014-2020 ‘Dottorati innovativi con caratterizzazione industriale' XXXIV Ciclo (Fellowship DOT1318705 to C.F., CUP: E66C18000940007). C.F. is a PhD student of the Doctorate in Veterinary Sciences of the University of Napoli 'Federico II'.

Institutional Review Board Statement: Not applicable.

Informed Consent Statement: Not applicable.

Data Availability Statement: The data presented in this study are available on request from the corresponding author.

Acknowledgments: We thanks the Italian Association for Cancer Research, Regione Campania, and Ministero dell'Istruzione, Università e Ricerca for their support.

Conflicts of Interest: The authors declare no conflict of interest.

\section{References}

1. Hamidi, H.; Ivaska, J. Every step of the way: Integrins in cancer progression and metastasis. Nat. Rev. Cancer 2018, 18, 533-548. [CrossRef] [PubMed]

2. Geiger, B.; Bershadsky, A.; Pankov, R.; Yamada, K.M. Transmembrane crosstalk between the extracellular matrix-Cytoskeleton crosstalk. Nat. Rev. Mol. Cell Biol. 2001, 2, 793-805. [CrossRef] [PubMed]

3. Zaidel-Bar, R.; Itzkovitz, S.; Ma'ayan, A.; Iyengar, R.; Geiger, B. Functional atlas of the integrin adhesome. Nat. Cell Biol. 2007, 9, 858-867. [CrossRef] [PubMed]

4. Takada, Y.; Ye, X.; Simon, S. The integrins. Genome Biol. 2007, 8, 215. [CrossRef]

5. Carlevato, M.T.; Trusolino, L.; Serini, G.; Valente, G.; Orlandi, F.; Angeli, A.; Cortesina, G.; Marchisio, P.C. Differential integrin expression in thyroid and laryngeal carcinomas. Anticancer Res. 1996, 16, 2379-2384.

6. Hoffmann, S.; Maschuw, K.; Hassan, I.; Reckzeh, B.; Wunderlich, A.; Lingelbach, S.; Zielke, A. Differential pattern of integrin receptor expression in differentiated and anaplastic thyroid cancer cell lines. Thyroid 2005, 15, 1011-1020. [CrossRef]

7. Vitale, M.; Bassi, V.; Fenzi, G.; Macchia, P.E.; Salzano, S.; Rossi, G. Integrin expression in thyroid cells from normal glands and nodular goiters. J. Clin. Endocrinol. Metab. 1993, 76, 1575-1579. [CrossRef]

8. Vitale, M.; Di Matola, T.; Fenzi, G.; Illario, M.; Rossi, G. Fibronectin is required to prevent thyroid cell apoptosis through an integrin-mediated adhesion mechanism. J. Clin. Endocrinol. Metab. 1998, 83, 3673-3680. [CrossRef]

9. Vitale, M.; Illario, M.; Di Matola, T.; Casamassima, A.; Fenzi, G.; Rossi, G. Integrin binding to immobilized collagen and fibronectin stimulates the proliferation of human thyroid cells in culture. Endocrinology 1997, 138, 1642-1648. [CrossRef]

10. Vitale, M.; Casamassima, A.; Illario, M.; Bassi, V.; Fenzi, G.; Rossi, G. Cell-to-cell contact modulates the expression of the beta 1 family of integrins in primary cultures of thyroid cells. Exp. Cell Res. 1995, 220, 124-129. [CrossRef]

11. Serini, G.; Trusolino, L.; Saggiorato, E.; Cremona, O.; De Rossi, M.; Angeli, A.; Orlandi, F.; Marchisio, P.C. Changes in integrin and E-cadherin expression in neoplastic versus normal thyroid tissue. J. Natl. Cancer Inst. 1996, 88, 442-449. [CrossRef] [PubMed]

12. Dahlman, T.; Grimelius, L.; Wallin, G.; Rubin, K.; Westermark, K. Integrins in thyroid tissue: Upregulation of alpha2beta1 in anaplastic thyroid carcinoma. Eur. J. Endocrinol. 1998, 138, 104-112. [CrossRef] [PubMed]

13. Celetti, A.; Garbi, C.; Consales, C.; Cerrato, A.; Greco, D.; Mele, E.; Nitsch, L.; Grieco, M. Analysis of cadherin/catenin complexes in transformed thyroid epithelial cells: Modulation by beta 1 integrin subunit. Eur. J. Cell Biol. 2000, 79, 583-593. [CrossRef] [PubMed]

14. Chernaya, G.; Mikhno, N.; Khabalova, T.; Svyatchenko, S.; Mostovich, L.; Shevchenko, S.; Gulyaeva, L. The expression profile of integrin receptors and osteopontin in thyroid malignancies varies depending on the tumor progression rate and presence of BRAF V600E mutation. Surg. Oncol. 2018, 27, 702-708. [CrossRef] [PubMed]

15. Di Matola, T.; Mueller, F.; Fenzi, G.; Rossi, G.; Bifulco, M.; Marzano, L.A.; Vitale, M. Serum withdrawal-induced apoptosis in thyroid cells is caused by loss of fibronectin-integrin interaction. J. Clin. Endocrinol. Metab. 2000, 85, 1188-1193. [CrossRef] [PubMed] 
16. Illario, M.; Amideo, V.; Casamassima, A.; Andreucci, M.; di Matola, T.; Miele, C.; Rossi, G.; Fenzi, G.; Vitale, M. Integrin-dependent cell growth and survival are mediated by different signals in thyroid cells. J. Clin. Endocrinol. Metab. 2003, 88, 260-269. [CrossRef] [PubMed]

17. Illario, M.; Cavallo, A.L.; Monaco, S.; Di Vito, E.; Mueller, F.; Marzano, L.A.; Troncone, G.; Fenzi, G.; Rossi, G.; Vitale, M. Fibronectin-Induced Proliferation in Thyroid Cells Is Mediated by \{alpha\}v\{beta\}3 Integrin through Ras/Raf-1/MEK/ERK and Calcium/CaMKII Signals. J. Clin. Endocrinol. Metab. 2005, 90, 2865-2873. [CrossRef]

18. Kitajiri, S.; Hosaka, N.; Hiraumi, H.; Hirose, T.; Ikehara, S. Increased expression of integrin beta-4 in papillary thyroid carcinoma with gross lymph node metastasis. Pathol. Int. 2002, 52, 438-441. [CrossRef]

19. Zhuang, Z.N.; Xu, Z.J.; Zhou, Q.; Xu, X.Z.; Tian, J.; Liu, Y.F.; Guo, S.; Wang, J.Y.; Xu, K.S. Clinical significance of integrin beta6 as a tumor recurrence factor in follicular thyroid carcinoma. Head Neck 2014, 37, 1439-1447. [CrossRef]

20. Smit, J.W.; van der Pluijm, G.; Vloedgraven, H.J.; Lowik, C.W.; Goslings, B.M. Role of integrins in the attachment of metastatic follicular thyroid carcinoma cell lines to bone. Thyroid 1998, 8, 29-36. [CrossRef]

21. Cockburn, J.G.; Richardson, D.S.; Gujral, T.S.; Mulligan, L.M. RET-mediated cell adhesion and migration require multiple integrin subunits. J. Clin. Endocrinol. Metab. 2010, 95, E342-E346. [CrossRef] [PubMed]

22. Noh, T.W.; Soung, Y.H.; Kim, H.I.; Gil, H.J.; Kim, J.M.; Lee, E.J.; Chung, J. Effect of \{beta\}4 integrin knockdown by RNA interference in anaplastic thyroid carcinoma. Anticancer Res. 2010, 30, 4485-4492. [PubMed]

23. Gao, J.; Aksoy, B.A.; Dogrusoz, U.; Dresdner, G.; Gross, B.; Sumer, S.O.; Sun, Y.; Jacobsen, A.; Sinha, R.; Larsson, E.; et al. Integrative analysis of complex cancer genomics and clinical profiles using the cBioPortal. Sci. Signal. 2013, 6, pl1. [CrossRef] [PubMed]

24. Salvati, A.; Gigantino, V.; Nassa, G.; Giurato, G.; Alexandrova, E.; Rizzo, F.; Tarallo, R.; Weisz, A. The Histone Methyltransferase DOT1L Is a Functional Component of Estrogen Receptor Alpha Signaling in Ovarian Cancer Cells. Cancers 2019, 11, 1720. [CrossRef] [PubMed]

25. Love, M.I.; Huber, W.; Anders, S. Moderated estimation of fold change and dispersion for RNA-seq data with DESeq2. Genome Biol. 2014, 15, 550. [CrossRef]

26. Benjamini, Y.; Cohen, R. Weighted false discovery rate controlling procedures for clinical trials. Biostatistics 2017, 18, 91-104. [CrossRef] [PubMed]

27. Agrawal, N.; Akbani, R.; Aksoy, B.A.; Ally, A.; Arachchi, H.; Asa, S.L.; Auman, J.T.; Balasundaram, M.; Balu, S.; Baylin, S.B.; et al. Integrated genomic characterization of papillary thyroid carcinoma. Cell 2014, 159, 676-690. [CrossRef]

28. Haugen, B.R.; Alexander, E.K.; Bible, K.C.; Doherty, G.M.; Mandel, S.J.; Nikiforov, Y.E.; Pacini, F.; Randolph, G.W.; Sawka, A.M.; Schlumberger, M.; et al. 2015 American Thyroid Association Management Guidelines for Adult Patients with Thyroid Nodules and Differentiated Thyroid Cancer: The American Thyroid Association Guidelines Task Force on Thyroid Nodules and Differentiated Thyroid Cancer. Thyroid 2015, 26, 1-133. [CrossRef]

29. Liang, C.C.; Park, A.Y.; Guan, J.L. In vitro scratch assay: A convenient and inexpensive method for analysis of cell migration in vitro. Nat. Protoc. 2007, 2, 329-333. [CrossRef]

30. Barczyk, M.; Carracedo, S.; Gullberg, D. Integrins. Cell Tissue Res. 2010, 339, 269-280. [CrossRef] [PubMed]

31. Miettinen, M.; Virtanen, I. Expression of laminin in thyroid gland and thyroid tumors: An immunohistologic study. Int. J. Cancer 1984, 34, 27-30. [CrossRef] [PubMed]

32. Walker, C.; Mojares, E.; Del Rio Hernandez, A. Role of Extracellular Matrix in Development and Cancer Progression. Int. J. Mol. Sci. 2018, 19, 3028. [CrossRef]

33. Kendall, C.H.; Sanderson, P.R.; Cope, J.; Talbot, I.C. Follicular thyroid tumours: A study of laminin and type IV collagen in basement membrane and endothelium. J. Clin. Pathol. 1985, 38, 1100-1105. [CrossRef]

34. Vitale, M.; Bassi, V.; Illario, M.; Fenzi, G.; Casamassima, A.; Rossi, G. Loss of polarity and de novo expression of the beta 1 family of integrins in thyroid tumors. Int. J. Cancer 1994, 59, 185-190. [CrossRef]

35. Ibaragi, S.; Shimo, T.; Hassan, N.M.; Isowa, S.; Kurio, N.; Mandai, H.; Kodama, S.; Sasaki, A. Induction of MMP-13 expression in bone-metastasizing cancer cells by type I collagen through integrin alpha1beta1 and alpha2beta1-p38 MAPK signaling. Anticancer Res. 2011, 31, 1307-1313. [PubMed]

36. Nones, K.; Waddell, N.; Song, S.; Patch, A.M.; Miller, D.; Johns, A.; Wu, J.; Kassahn, K.S.; Wood, D.; Bailey, P.; et al. Genome-wide DNA methylation patterns in pancreatic ductal adenocarcinoma reveal epigenetic deregulation of SLIT-ROBO, ITGA2 and MET signaling. Int. J. Cancer 2014, 135, 1110-1118. [CrossRef]

37. Ding, W.; Fan, X.L.; Xu, X.; Huang, J.Z.; Xu, S.H.; Geng, Q.; Li, R.; Chen, D.; Yan, G.R. Epigenetic silencing of ITGA2 by MiR-373 promotes cell migration in breast cancer. PLoS ONE 2015, 10, e0135128. [CrossRef]

38. Chuang, Y.C.; Wu, H.Y.; Lin, Y.L.; Tzou, S.C.; Chuang, C.H.; Jian, T.Y.; Chen, P.R.; Chang, Y.C.; Lin, C.H.; Huang, T.H.; et al. Blockade of ITGA2 Induces Apoptosis and Inhibits Cell Migration in Gastric Cancer. Biol. Proced. Online 2018, 20. [CrossRef]

39. Ren, D.; Zhao, J.; Sun, Y.; Li, D.; Meng, Z.; Wang, B.; Fan, P.; Liu, Z.; Jin, X.; Wu, H. Overexpressed ITGA2 promotes malignant tumor aggression by up-regulating PD-L1 expression through the activation of the STAT3 signaling pathway. J. Exp. Clin. Cancer Res. 2019, 38, 485. [CrossRef]

40. Qin, A.; Liu, Q.; Wang, J. Ropivacaine inhibits proliferation, invasion, migration and promotes apoptosis of papillary thyroid cancer cells via regulating ITGA2 expression. Drug Dev. Res. 2020, 81, 700-707. [CrossRef] 
41. Jain, M.; Zhang, L.; Boufraqech, M.; Liu-Chittenden, Y.; Bussey, K.; Demeure, M.J.; Wu, X.; Su, L.; Pacak, K.; Stratakis, C.A.; et al. ZNF367 inhibits cancer progression and is targeted by miR-195. PLoS ONE 2014, 9, e101423. [CrossRef]

42. Liu, H.; Chen, X.; Lin, T.; Yan, J.; Jiang, S. MicroRNA-524-5p suppresses the progression of papillary thyroid carcinoma cells via targeting on FOXE1 and ITGA3 in cell autophagy and cycling pathways. J. Cell Physiol. 2019, 234, 18382-18391. [CrossRef]

43. Friedl, P.; Wolf, K. Tumour-cell invasion and migration: Diversity and escape mechanisms. Nat. Rev. Cancer 2003, 3, 362-374. [CrossRef]

44. Brooks, P.C.; Silletti, S.; von Schalscha, T.L.; Friedlander, M.; Cheresh, D.A. Disruption of angiogenesis by PEX, a noncatalytic metalloproteinase fragment with integrin binding activity. Cell 1998, 92, 391-400. [CrossRef]

45. Dumin, J.A.; Dickeson, S.K.; Stricker, T.P.; Bhattacharyya-Pakrasi, M.; Roby, J.D.; Santoro, S.A.; Parks, W.C. Pro-COase-1 (matrix metalloproteinase-1) binds the alpha(2)beta(1) integrin upon release from keratinocytes migrating on type I CO. J. Biol. Chem. 2001, 276, 29368-29374. [CrossRef] 